\title{
The Securitisation of Kurdish Self-Determination as A Challenge for the Sectarian Balance of Power in the Middle East
}

\begin{abstract}
The article addresses current questions concerning the Kurdish situation before and after the invasion and expansion of ISIS. It applied the theory of securitisation to study the tangled circumstances and frameworks of Kurdish claims, underlining their attempts at gaining their much-desired independence. This elaboration enables one to recognise the genesis and the local, regional and global context of international actions vis-à-vis Kurdish interests, and the possible supporters and opponents of the Kurdish project of statehood in the Middle East. It portrays also the current perception of Kurdish efforts to establish their own national and legal subjectivity that must be recognised by the majority of state actors in order to meet the indispensable criteria of international law.

This article is particularly important in the context of recent developments in the Middle East. First of all, it refers to pressures, as well as openly offensive actions targeting the interests and territories controlled by the Kurds in Turkey during the existence of the so-called Islamic State. Secondly, it reflects on actors' reactions in the international arena, including the countries of the Middle East, towards the independence referendum in Iraqi Kurdistan, as well as on direct actions aimed at shaping a new geopolitical order after the fall of ISIS (attack by Iraqi troops in Kirkuk or the Turkish army in Afrin).
\end{abstract}

Keywords: Kurds, Middle East, independence, constitutive and declarative international recognition, securitisation

The article addresses current questions concerning the Kurdish situation before and after the invasion and expansion of ISIS. It applies the theory of securitisation ${ }^{1}$ to study the tangled circumstances and frameworks of Kurdish claims, underlining their attempts to gain their

1 'The essence of the theory is the idea that something becomes a security problem, not only because it constitutes an objective threat to the state, but becomes a matter of security when the securitizing actor (often the state) argues that something is an existential threat to a reference object and must be dealt with immediately as soon as its purpose is to survive, B. Buzan, O. Wæver, J. de Wilde, 1998 and B. Buzan, O. Weaver, 2003. 
much-desired independence. This elaboration enables one to recognise the genesis and the local, regional and global context of international actions vis-à-vis Kurdish interests, and the possible supporters and opponents of the Kurdish project of statehood in the Middle East. It portrays also the current perception of Kurdish efforts through the internal and external prism of the securitisation process towards establishing its own national and legal entity, which must be recognised by the majority of state actors in order to meet the indispensable criteria of international law.

This article is particularly important in the context of recent developments in the Middle East. First of all, it refers to pressures, as well as open offensive actions targeting the interests and territories controlled by Kurds in Turkey during the existence of the self-declared Islamic State. Secondly, it reflects on actors' reactions in the international arena, including the countries of the Middle East, towards the independence referendum in Iraqi Kurdistan, as well as on direct actions aimed at shaping a new geopolitical order after the fall of ISIS (attack by Iraqi troops in Kirkuk or the Turkish army in Afrin).

\section{The Future Kurdish Country and the Significance of International Recognition - Constitutive or Declarative - in the Global Context of Securitisation: A Perspective}

In accordance with a classical conception of statehood, every state organism is very often determined by three universal elements, namely territorial distinction, population and effective power, including the ability to establish and maintain diplomatic relations. In the case of the Kurdish nation, all of them apply and can be strongly securitised, but with some limits and exceptions.

First of all, Kurds settle a large area in the Middle East, i.e. Turkey, Iraq, Iran, Syria, in Central Asia, i.e. Afghanistan, and in the South Caucasus, i.e. Armenia and Azerbaijan. Their presence has a considerable impact on the geopolitical situation in these regions and increases the vulnerability to radical responses to securitised Kurdish initiatives. The total area of so-called Kurdistan is about 450 thousand square kilometres, nearly half of which is located in Turkey. Kurdistan borders with Turkey to the North and North-West, with the Mediterranean to the West, with Syria and Iraq to the South, with Iran to the East, and with Armenia to the North-East (see also: Fuad, 2001, p. 15). The only dominant obstacle to meet the territorial condition of securitised statehood is the lack of real, sovereign control of a settled area, which is fundamentally limited due to the fact that Kurds live nowadays within independent states and are forced to respect all existing constitutional orders.

The second aspect of this conceptual approach to state analysis is population. In the case of the Kurds, it varies between 25 and 35 million (BBC, 2017). ${ }^{2}$ The largest segment

2 A precise determination of the number of Kurds is, however, extremely complicated due to the difficulty in accessing the relevant statistics, in particular in Middle Eastern countries. Therefore, it is likely for one to come across data that is slightly different among experts on Kurdish issues (Giedz, 2002, p. 13). 
is located in Turkey, amounting to around 14.7 million (18\% of the Turkish population). Besides, Kurds also inhabit the following countries: Iraq - 5.5 million (17.5\% of the Iraqi population), Iran -8.1 million (10\% of the Iranian population) and Syria - 1.7 million (9.7\% of the Syrian population) (BBC, 2017). A large number of Kurds also lives in Armenia - 1 million - and Afghanistan - around 200 thousand. There is also the Kurdish diaspora settled outside this area (around 7 million). In particular, 2 million Kurds live in Europe, for instance in Germany or Sweden (Fuad, 2001, p. 5). The Kurdish diaspora with its increasing impact may play a crucial role in spreading the securitised Kurdish ambitions and national claims, which at the moment are treated as existential reference objects by the international public opinion. For instance, several times, waves of protests organised by Kurds have swept through many European cities, for example in Germany, Belgium or France (the impact and role of the Kurdish Institute of Paris).

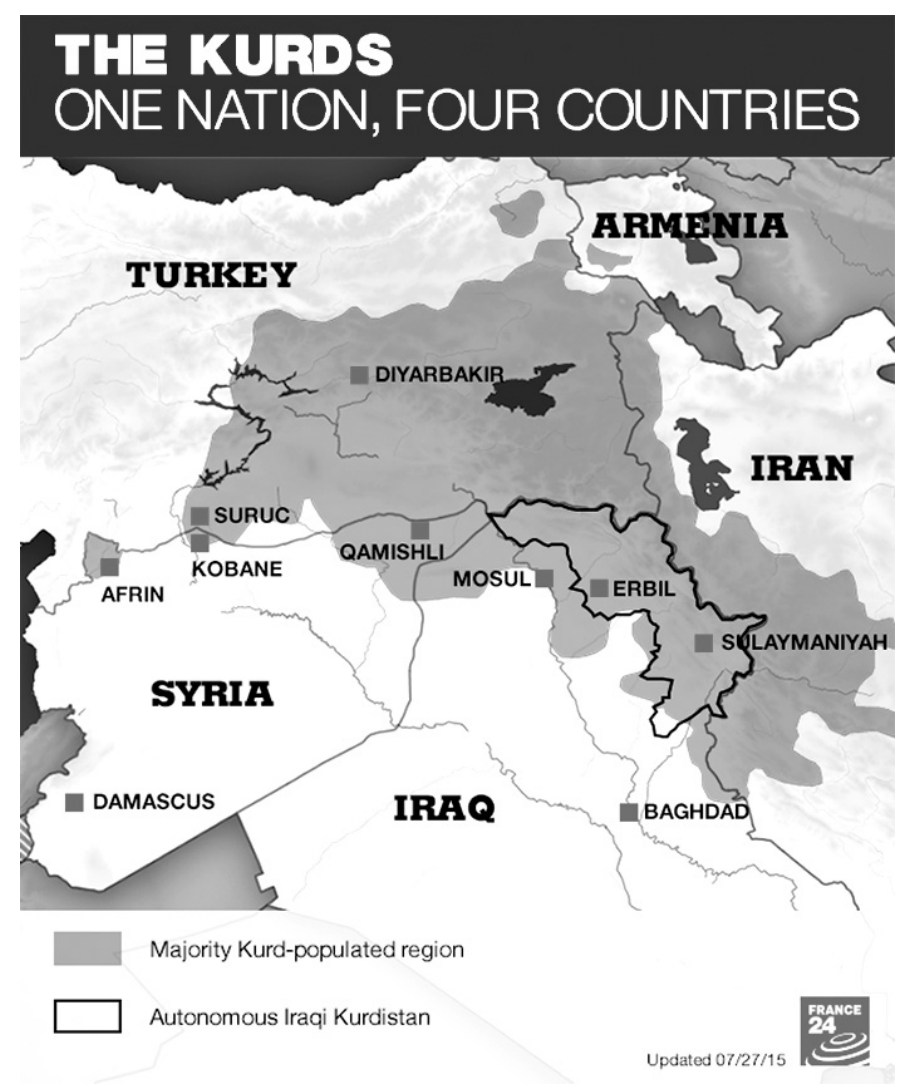

Chart 1. Kurdish geopolitics in the Middle East

Source: S. Leduc, The Kurds: The World's Largest Stateless Nation, FRANCE 24, http:// www.france24.com/en/20150730-who-are-kurds-turkey-syria-iraq-pkk-divided, [access: 10.03.2018]. 
The last point to be addressed in this section is the effective authority to exercise rights and obligations in a given society. The approach to this question is more complicated. To some extent, Kurds in several states are more or less represented by elected delegations, for instance, Kurds in Iraq or in Turkey. Of course, without any sufficient control over the territories inhabited by Kurds, it is nearly impossible to acknowledge this power as effective.

Furthermore, apart from the abovementioned state-creating elements, it is to be emphasised that a state cannot exist without being recognised by other countries on a global scale, at least by the vast majority of them. So what does this mean precisely? It simply defines the way to accept a specific factual situation in a process of statehood creation and bestow it with legal significance. Currently, there are two types of international recognition. Firstly, each state can be recognised internationally in a constitutive manner, which means that the state becomes subject to international law (and hence acquires subjectivity), through the act of recognition alone (Shaw, 2008). Secondly, there is the declarative way of international recognition. In that sense, the fulfilment of the actual requirements for statehood involves the sufficient premise for the existence of the state in accordance with international law and, in this case, recognition is merely a political, not a legal act (Shaw, 2008). What should be noted in this regard is that the greater the recognition at the international level, the fewer the requirements for the objective demonstration of fulfilling these conditions (Bierzanek, Symonides, 2004). Conversely, the less international recognition is achieved, the more carefully other states are observing how these criteria are being met (Bierzanek, Symonides, 2004).

\section{Legal-International Subjectivity and Aims of a Possible Securitised Kurdish Self-Determination}

The subjectivity of state entities is another significant aspect of this analysis in the context of current Kurdish claims and the particular aims in the process of securitisation. Entities capable of carrying out independent international activity, and aware of their role and place in the world, possess international and political subjectivity. Legal and international subjectivity, however, refers to those actors possessing both international and political subjectivity and the legal capacity to act in international relations. This relates to all states and some international governmental organisations (the case of the European Union after the implementation of the Treaty of Lisbon in 2009).

In this regard, Kurds intend to achieve a securitised subjectivity (political and legal) and official status of the state, that is to become a sovereign geopolitical entity that acts in accordance with international law. As mentioned above, territory (sea, land, subsoil and airspace), population (citizens of the state), state power (effective power over territory and population), independence of the state from other states in decision-making processes, and the ability to maintain relations with other states resulting from being recognised by them and the United Nations, are the most important constitutional features of a state. 
At this stage, the complex status of Kosovo could be a comparable example. Kosovar Albanians struggled strongly over the practical implementation of their right to selfdetermination, which led to an official proclamation of independence in February 2008. The Republic of Kosovo was eventually recognised by 111 states out of the 194 that exist in the international environment (including 193 members of the United Nations). In October 2008, the UN General Assembly at the request of Serbia handed over the case of Kosovo's independence to the International Court of Justice. In July 2010, the International Court of Justice recognised that the declaration of independence announced by Kosovo in 2008 does not violate international law. Nevertheless, some experts claim that it still constitutes rather a part recognition of state subjectivity on a global scale. Furthermore, Kosovo has not yet joined the United Nations and has not been recognised by China and Russia. The situation in Kosovo is still very unstable due to tensions with Serbia.

\section{The Vision of Kurdistan3 - Basic Historical Background and First Attempts for Establishing Autonomy and Self-Determination as a Main Aim of Multi-Level Securitisation}

The Kurds constitute an ethnic group related to the Medes and Persians. The history of this community dates back to antiquity. One hypothesis assumes that they are descended from the Medes who, together with the Babylonians, overthrew the Assyrian Empire in the years 614-610 BCE (Giedz, 2002 and Grgies, 1997). The capture of Nineveh by King Kyaksares in $612 \mathrm{BCE}$ is often referred to as the starting point in the history of the Kurds, giving way a few dozen years later to the Persians and becoming part of the Achaemenid monarchy (Giedz, 2002).

The word Kurd appeared for the first time in sources of Persian origin in 226 CE. In the seventh century, they were conquered by Arabs and islamised, and in the eleventh century were again conquered by the Seljuks (Grgies, 1997). The current name dates from this period. One of the most famous Kurds was Salah ad-Din, or Saladin, who took Jerusalem back from the hands of the crusaders in the twelfth century.

After the victory of the Ottoman Sultan Selim I over the Safavids in the Battle of the Chaldidy Plain in 1514, the majority of Kurds lived within the borders of the Ottoman Empire. This division was enshrined in the Treaty of 1639 between Abbas and Sultan Murad IV. In the years 1826-1885, the Great Ottoman uprisings took place in the Ottoman Empire.

3 Currently, Kurdistan is an autonomous administrative unit that is a federal entity within Iraq. It is located in the north of Iraq and comprises three whole provinces (As-Sulajmanijja, Dahuk and Irbil) and three others only partially (Dijala, Niniwa and Kirkuk). The capital of the autonomous unit is Erbil, called Hewlêr in Kurdish. 
The Sèvres peace treaty, concluded after the end of the First World War, established autonomy for the Kurds, with the option of gaining independence in the future (Historical Encyclopaedia of the World, 2002).

On 10 October 1921, Kurds proclaimed the Kingdom of Kurdistan. The discovery of oil deposits in Kurdish territories, however, in what is today northern Iraq, caused the Entente to withdraw its support for the project of an independent Kurdistan, and its lands were divided by the Treaty of Lausanne in 1923 between the Young Turks, secular Turkey, Persia, the British mandate of the League of Nations in Iraq, and the French in Syria. In 1924, British troops liquidated the Kingdom of Kurdistan.

Table 1. First attempts to establish autonomy and self-determination in the twentieth and twenty-first centuries

\begin{tabular}{|c|c|}
\hline Area & Description \\
\hline $\begin{array}{l}\text { Tur- } \\
\text { key }\end{array}$ & $\begin{array}{l}\text { - } \text { the establishment of the Kurdish National Committee in Ankara, in } 1908 \\
\text { _ in nationalist Turkey of Atatürk, the Kurds were considered as part of the indivisible Turkish } \\
\text { nation, and were known as Turks of the Mountain. It was forbidden to use the Kurdish lan- } \\
\text { guage and to celebrate the traditional Kurdish holiday of the new year (Newroz). This resulted } \\
\text { in uprisings breaking out in } 1925,1930 \text { and 1936. The authorities displaced Kurds into Anato- } \\
\text { lia, to tear them away from the rest of the community, and also Peshmerga (Kurdish partisans) } \\
\text { _ in the 1970s, the Maoist Kurdish Workers' Party under Abdullah Öcalan, spearheading the } \\
\text { establishment of an independent Kurdistan under a communist regime, gained a lot of mo- } \\
\text { mentum among Turkish Kurds } \\
\text { - in December 2016, the Kurdish Institute in Istanbul was stormed and closed by the police after } \\
\text { the government announced the suspension of nearly } 100 \text { associations under Article } 11 \text { of the } \\
\text { state of emergency introduced after the coup d'état in Turkey in July } 2016\end{array}$ \\
\hline Iran & $\begin{array}{l}\text { - in 1946, Iranian Kurds, in agreement with the Iraqi people, proclaimed the Kurdish Republic in } \\
\text { Mahabad. This attempt was bloody (15,000 victims), suppressed by the Iranian army with the } \\
\text { participation of British troops and American aid (Zdanowski, 2010) } \\
\text { - on } 31 \text { March 1947, after a secret trial, the leader of the Iranian Kurds, Kazi Muhamed, and } \\
\text { all members of the government of the Republic were executed. Troops of the Barzani clan } \\
\text { withdrew to Iraq }\end{array}$ \\
\hline Iraq & $\begin{array}{l}\text { - uprisings in Iraq were suppressed in } 1922 \text { and } 1924 \text { by British rule } \\
\text { - in May 1992, elections to the Kurdish parliament were held } \\
\text { - } \text { in the mid-1990s, a struggle between the Kurdistan Democratic Party (KDP), centred around } \\
\text { the Masud Barzani family, and the pro-Iranian Patriotic Union of Kurdistan (PUK), organised } \\
\text { around the person of Jalal Talabani, took place } \\
\text { - in early 2006, the two Kurdish areas of Erbil, led by the KDP, and Sulaymaniyah, ruled by the } \\
\text { PUK, were united in one region (Jamsheer, 2007). A referendum was to take place in } 2007 \text { to } \\
\text { determine the final borders of the Kurdish region, but it was postponed indefinitely }\end{array}$ \\
\hline Syria & $\begin{array}{l}\text { - in January 2014, Syrian Kurds proclaimed independence in the region of Rojava in the north of } \\
\text { Syria, inhabited by } 2.5 \text { million people. The province, as a result of the revolution in November } \\
\text { 2013, secured autonomy officially announced on } 9 \text { January } 2014 \text { (Charter of the Social Con- } \\
\text { tract, 2014). Rojava consists of three cantons: Jazira, Kobani and Afrin. The city of Al-Kamiszla } \\
\text { was proclaimed as capital on } 21 \text { January 2014. Rojavas autonomy was not recognised by the } \\
\text { Syrian government (Banco, 2014). The Kurdish-controlled province is involved in a civil war } \\
\text { with Syria }\end{array}$ \\
\hline
\end{tabular}

Source: Own elaboration. 
The Kurds use a language belonging to the Indo-European family, divided into four dialects. Most of them adhere to Sunni Islam (Fuad, 2001, p. 27-32), while quite often Yazidi are also encountered among them. The Kurds, unlike the Arabs, have not developed a uniform literary language to this day. The complex history of the Kurds is probably connected to the very mountainous terrain, which characterises and divides their vast inhabited region into four main areas, and which has prevented the Kurds from creating a uniform language:

- Northern Kurdish, Kurmanji, is spoken by the majority of Kurds in Turkey, Syria, the CIS and by some Kurds in Iraq and Iran, about $60 \%$ of Kurds in total

- Central Kurdish, Sorani, is spoken by the majority of Kurds in Iraq and Iran, i.e. 30\% of Kurds

- Western Kurdish, Zazaki, is spoken mainly in Turkish Kurdistan

- Eastern Kurdish, Gurani, is spoken in the south of the Kurdish regions of Iraq and Iran

Cultural, religious and linguistic aspects closely affect the sectarian balance of power in the Middle East. These clear ethnic, demographic, religious, ideological and socio-economic differences determine the geopolitics of this area and have a considerable impact on the securitisation process of the Kurdish self-determination efforts in the Middle East. This is due to the presence of diverse religious groups such as Sunni, Shiites, Alevites, Yazidis and Christians in the Middle East.

Lastly, it is worth paying attention to the role that the Kurdish issue plays today. This is particularly true in the case of the EU-Turkish negotiations or the future of Iraq after the collapse of the so-called Islamic State. In the former case, the EU's position is clearly defined. Turkey as a candidate country should meet all the Copenhagen criteria of 1993. First and foremost, those which refer to the establishment of stable democratic institutions, the rule of law, and the protection of human rights and minorities. That is why in the next sections I will focus mainly on the current situation of the Kurds in Turkey and Iraq, as there are differences in the approach to the Kurdish issue as a securitised problem among countries of the Middle East. The most important differences include the radical assimilation policy in accordance with the idea of the so-called melting pot as regards Kurds in Turkey, and the possibility of organising a referendum and acquiring a relatively autonomous status in Iraq. The specificity of Turkish and Iraqi responses to Kurdish activities in their territories, and EU policy and its initial and short-term impact on improving the situation of Kurds in Turkey will also be discussed. What is crucial, however, is that the situation of Kurds in Turkey, Iraq and Syria is inextricably linked after the expansion and geopolitical changes wrought by ISIS in the Middle East. 


\section{The Kurdish Question in Turkey in the Twentieth and Twenty-First Centuries}

After the Second World War, the Kurdish issue has been securitised as a potential existential threat to the internal constitutional order and security of citizens in countries with strong Kurdish communities in the Middle East. This is no different in Turkey. In the 1950s, after the first free elections and the defeat of the Kemalists, Turkish policies towards the Kurdish community were relaxed. The situation of the Kurds, however, was not improved significantly. Moreover, the political activity of Turkish Kurds in the international arena was rather limited. It was not until 1978 that the Kurdish Workers Party (PKK) emerged, and was initially underestimated by Turkey. Partiya Karkere Kurdistan (PKK) was founded on 27 November 1978. Abdullah Öcalan stood at the head of the new formation. 'Initially, PKK's goal was to accelerate the degradation of the existing social system by killing local Kurdish militia and Turkish government officials, often murdered with their families' (Kołodziejczyk, 2000, p. 256). The Turkish authorities carried out an anti-Kurdish campaign in the period between 1980 and 1983. In the early 1980s, independent Kurdistan, or at least the Turkish-Kurdish federation, became the main target.

After the 1980 coup in Turkey, the fact that Öcalan sought and gained refuge in Syria as well as the help that Syria granted to the PKK, have given cause for further political turmoil between Turkey and Syria and undoubtedly defined relations between the two countries (Fuad, 2001, p. 61). In 1994, Turkey launched a military offensive, which led to a Kurdish exodus into Iraq. Since then, Turkish troops have regularly crossed into neighbouring countries (especially in Iraq). The aim of the operations of the Turkish army was to eliminate Turkish-Kurdish bases there, which often led to regional conflict and destabilised the Middle East (Kukułka, 2003, p. 614).

In 1998, PKK's leader, Abdullah Öcalan, was detained at an airport in Rome under two international arrest warrants issued by Turkey and Germany. After a failed attempt to obtain political asylum in Italy, PKK's leader went to Africa, where he disappeared from the Greek embassy in which he had taken refuge, in the Kenyan capital of Nairobi in February 1999. He was taken to a Turkish prison, where in June of the same year, he was sentenced to death for treason and separatist activities. The verdict was not upheld and he has since been imprisoned in Turkey (Giedz, 2002,p. 13). Events relating to the detention of Öcalan, the trial against him and his sentence, have become factors uniting Kurds regardless of territory.

In the same year, Öcalan called on his followers to refrain from violence and start a dialogue with Ankara on the Kurdish issue. At the 2000 PKK Congress, the party agreed to use only political methods to serve the new purpose of fighting for the rights of the Kurds in Turkey. The estimates indicate that the organisation currently has 4,000-5,000 members, mainly located in northern Iraq, and thousands of supporters in Turkey and throughout Europe. It operates in Turkey, Europe and the Middle East. Aid is received from Syria and Iran, both of which aim to weaken the role of Turkey in the region. The Kurdistan Workers' 
Party was recognised by the European Union and the United States as a terrorist organisation. Around 37,000 people have died in the Kurdish-Turkish clashes between 1984 and 2007.

In 2003, the Kurdistan Workers' Party was renamed into Kongra-Gel (Kurdistan People's Congress). Kongra-Gel has abandoned the postulate of independence for the Kurdish community. At present, its main goal is to gain autonomy and respect for the rights of the Kurds. In 2004, however, Kurdish separatists broke off a unilateral ceasefire and resumed fighting with the Turks, which continues to this day.

The Kurdish issue is one of the many areas of dispute in EU-Turkey negotiations regarding EU membership that began in October 2005. Turkey first signed an EEC association agreement in 1963, gaining candidate status in 1999. Accession negotiations were launched on 3 October 2005. Kurds and their fundamental rights as a minority constitute a challenge for Turkish authorities, alongside the occupation of Cyprus and the recognition of the Armenian genocide. The condition of regulating the Kurdish issue must be fulfilled by Ankara because the European Union cannot afford another national conflict (Gazeta Wyborcza, 2005).

EU institutions, and in particular the European Parliament, have repeatedly called for far-reaching changes in Turkish legislation and policy towards the Kurdish population. Similarly, the EU has urged the PKK to lay down its arms, which would be an impetus for the resumption of talks, and has condemned the terrorist activities of this organisation. In addition, it is explicitly emphasised that Turkey's fight against terrorism (identified with the PKK by the Turkish and EU authorities) is in violation of the fundamental rights of the Turkish population. This struggle, at the same time, is unfortunately also a mechanism to block any political initiative to solve the Kurdish issue (European Parliament, 2006). Nevertheless, Turkey's efforts to join the European Union have cleared but not significantly improved the situation of the Kurdish population in Turkey. In 2006, the Turkish government allowed the broadcasting of programs in Kurdish by Kurdish TV and radio stations (Gazeta Wyborcza, 2006).

The situation of the Kurdish population has improved considerably since 2002. At that time, EU demands for rights and privileges for the Kurdish minority were met. Statutory freedom was guaranteed, unless it was aimed against the integrity of the Turkish state, whence it became subject to restrictions, determined as it is by the fear of Kurdish separatism. Turkey introduced the possibility of teaching and broadcasting in the Kurdish language in Eastern Turkey (Giedz, 2002, pp. 94-98). These small but significant changes (Turkey has not recognised the existence of a Kurdish community for a long time) show that the Kurdish issue is far from being resolved. Some argue that only when Turkey joins the EU, will the Kurds living there secure more rights and privileges.

Currently, the situation of the Kurds in Turkey has deteriorated due to the activities of PKK, radical actions carried out by the Turkish government and a change in the geopolitical balance of power after the ISIS invasion and the fiasco of trying to secure international and regional approval for the results of the referendum in Iraqi Kurdistan. 


\section{The Kurds on the Winding Path to Securitised Independence - The Case of Iraqi Kurdistan}

In 1946, Mustafa Barzani founded the Democratic Party of Kurdistan, which supported the uprising of the Kurdish Republic of Mahesa (Jamsheer, 2007). After a sojourn in the USSR, he returned to Iraq to trigger an uprising in 1961, which ended in 1970 with a settlement with Baghdad (Zdanowski, 2010). The Iraqi Kurds were recognised as a separate ethnic group and received autonomy. The Kurdish autonomous region was originally created in 1970 as a result of the Iraqi-Kurdish agreement. ${ }^{4}$

In 1988, the Iraqi government carried out the Al-Anfal operation in territories inhabited by the Kurds. This was aimed against both Kurdish armed organisations and civilians. On 16 March 1988, four to five thousand people were killed in the chemical attack on the city of Halabda, located in northern Iraq (Zdanowski, 2010). In total, until September of that year, according to various sources, between 50,000 and 200,000 people were killed (Farouk-Sluglett, Sluglett, 2003), while 300,000 Kurds were displaced to resettlement camps (Zdanowski, 2010).

By October 1991, the Kurdish forces had ousted Iraqi troops from Kurdistan, establishing a de facto independent Kurdish state (Kurdistan, however, was never declared independent). Authorities in the region were divided into two competing parties: the Democratic Party of Kurdistan (Mustafa Barzani) and the Patriotic Union of Kurdistan (Jalal Talabani).

After the Second Gulf War, Iraqi Kurdistan became the most stable part of the occupied country. The Kurds were actively involved in the processes of creating new sovereign state authorities. The first president-elect of post-war Iraq in 7 April 2005 was Jalal Talabani, a politician of the Patriotic Union of Kurdistan. The Kurdistan region, unlike the rest of Iraq, was an economically prosperous region. After the outbreak of the Sunni rebellion in 2014 and the proclamation of the Islamic State by Islamic jihadists in the north of Iraq and the east of Syria, the Kurds seized the region abandoned by the government of Kirkuk, to which they had claims. The government of Iraq, blaming Kurdish autonomy for supporting the jihadists, ceased to provide Kurdistan with income from oil, which led to Kurds withdrawing ministers from the Iraqi coalition government.

The referendum scheduled for 25 September 2017 in Iraqi Kurdistan was the closest the Kurdish population had been to independence in recent times. This official vote was criticised by almost all powerful states and international organisations, including the United States and the European Union. Nevertheless, Masoud Barzani - the President of the Iraqi Kurdistan Region and the leader of the Kurdistan Democratic Party (KDP) - made all necessary efforts to organise the referendum. Approximately 3.3 million Kurds voted, out of 4.5 million people entitled to vote (El-Ghobashy, 2017). Almost 92 per cent of all participants

4 In practice, this autonomy was only on paper until 1991 when, as a result of the First Gulf War, lost zones in the north and south of Iraq became no-fly zones for Iraqi aircraft. 
in the plebiscite were in favour of Kurdish self-determination. The results of the referendum have not been recognised internationally. What is worth noting is that Israel was the only state to support Kurdish independence (Strachota, 2017). The Kurdish Regional Government (KRG) assured in a statement issued in November 2017 that it would respect the decision of the Iraqi Supreme Federal Court regarding the unconstitutional nature of secession of any part of the country. It is necessary to highlight here that this action steered by KRG was political, rather than legal.

Taking into consideration the importance of the referendum as one of the most recent and official initiatives towards Kurdish statehood, it undoubtedly led to significant changes in the geopolitical position of the Kurds in the Middle East. The referendum process had many side effects, such as:

- tensions within the Kurdish community, different attitudes of individual political factions (KDP, PUK, PKK, PYD/YPG, KNC) culminating in the resignation of Masoud Barzani

- restriction of the autonomy of Iraqi Kurdistan

- open conflict with Iraq and the Iraqi invasion of Kirkuk

- Turkish intervention in Afrin

- deterioration of relations with Iran and Syria

- weakening of US and EU support

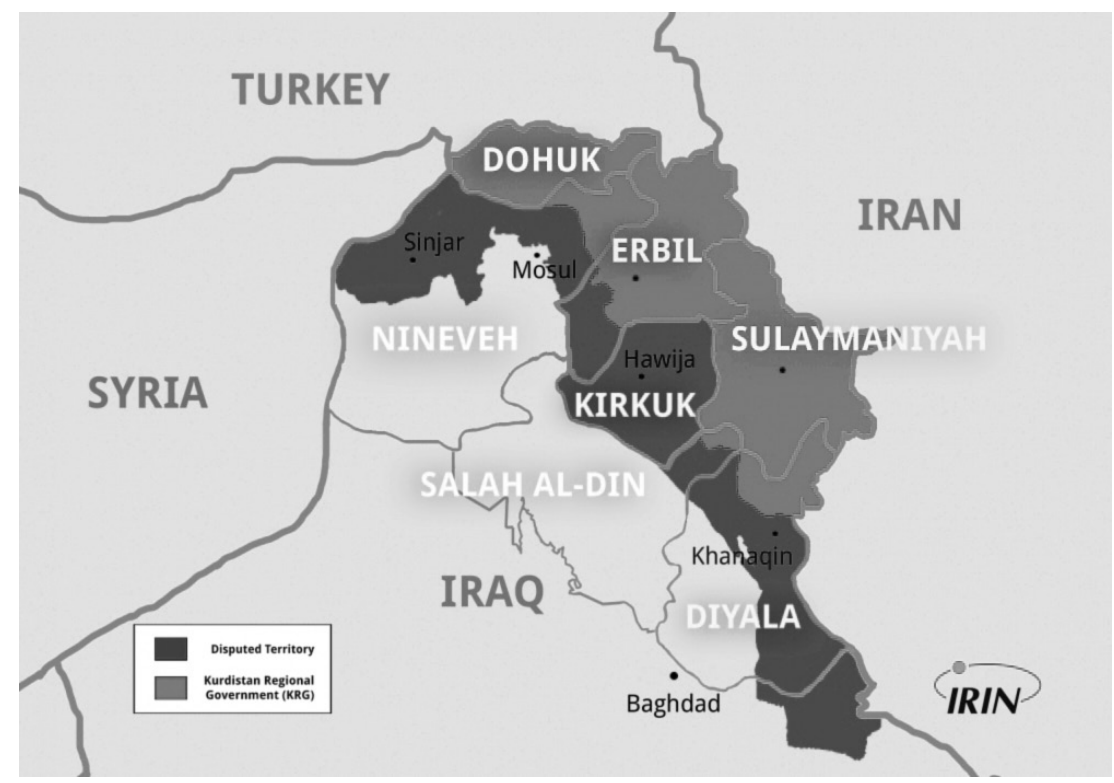

Map 1. The location of Iraqi Kurdistan in 2017

Source: IRIN, Iraqi Kurdistan has Voted for Independence. What Now?, 27 September 2017, http://www. refworld.org/docid/59ccb6f04.html [access: 10.03.2018]. 


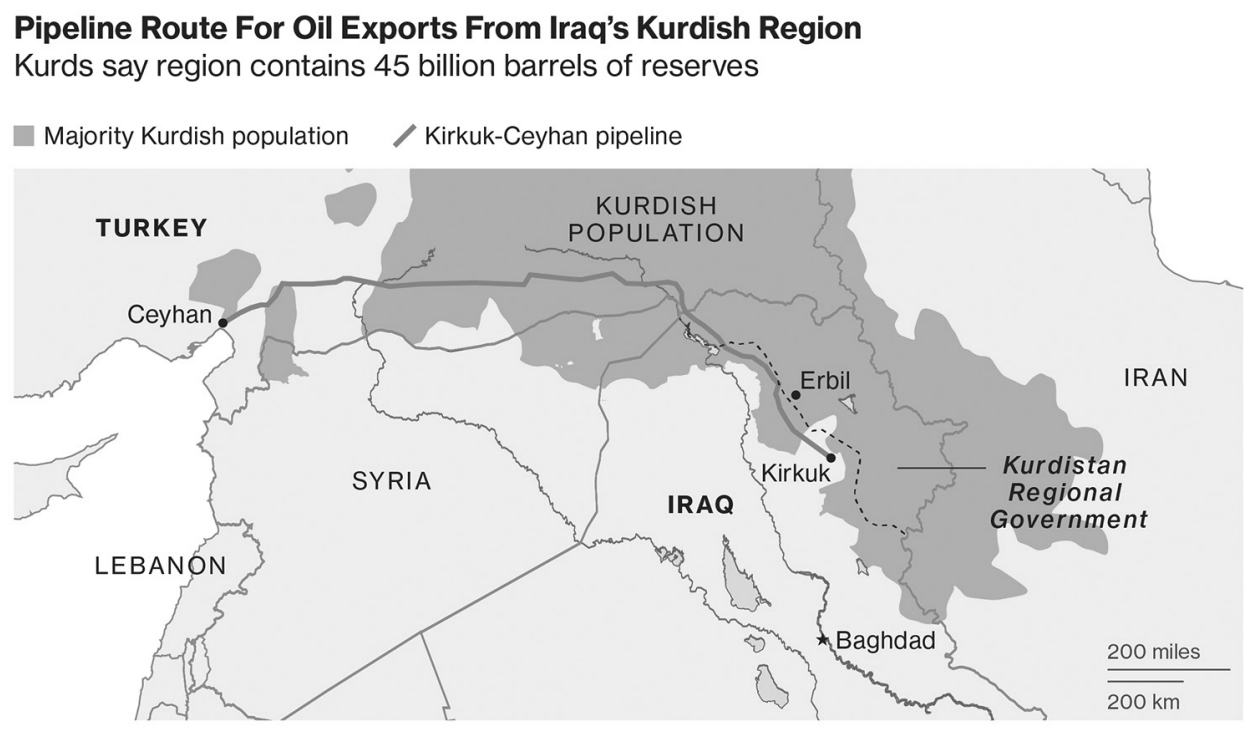

Bloomberg 栏

Map 2. Iraqi Kurdistan as an area of strategic resources

Source: A. Rascouet, K. Al Absary, How Iraq’s Kurdish Independence Referendum Could Impact Oil Markets, Bloomberg, 24 September 2017, https://www.bloomberg.com/news/articles/2017-09-20/iraq-s-kurdsseek-independence-what-impact-for-oil-markets, [access: 14.04.2018].

\section{The Securitisation of the Kurdish Case in the Middle East}

In this section, I use the theory of securitisation in order to carry out an analysis of major players as securitising actors, as well as examine perceptions of the Kurdish situation in the Middle East, particularly against the backdrop of loss of control and influence caused by ISIS in this area. Therefore, my aim is to provide a short introduction to this theoretical frame as a useful analytical and conceptual tool to research complex international issues.

The theory of securitisation was introduced in the 1980s. This conceptual methodology was presented for the first time by Ole Wæver in the framework of COPRI in 1995. The concept of securitisation was developed as part of the Copenhagen Peace Research Institute (COPRI). This was established in 1985. In January 2003, it was included in the Danish Institute for International Studies. O. Wæver, B. Buzan, J. de Wilde and L. Hansen are still affiliated with this centre. The name Copenhagen School was first used by B. McSweeney in 1994. The second generation of securitisation researchers in the framework of critical security studies include Juha Vuori, Thierry Balzacq, Lene Hansen and Holger Stritzel.

The first outlined methodological concept was the security sectors concept. 'Security sectors are areas / fields of activity or arenas that involve specific forms of security interac- 
tions and specific definitions of reference objects' (Williams, 2008). In the course of the research, representatives of the Copenhagen school distinguished the following security sectors: military, state / political, social, economic, and environmental protection (Buzan, Wæver, de Wilde, 1998).

B. Buzan, O. Waever and J. de Wilde argue that securitisation processes can take place within security sectors. Importantly, however, securitisation itself can occur in many security sectors, as opposed to a single one at a time. The classic security dimensions identified are a useful guideline for analysing the multi-dimensional nature of security.

The second concept - securitisation theory - boils down to the ontology of perceiving the world as an area organised by securitising actors, acts of speech and audience.'The essence of the theory is the idea that something becomes a security problem, not only because it constitutes an objective threat to countries (like in neorealism), but it becomes a matter of security when the securitizing actor (often the state) argues that something is an existential threat to an object and must be dealt with immediately as long as its purpose is to survive' (B. Buzan, O. Wæver, J. de Wilde, 1998 and B. Buzan, O. Weaver, 2003). Therefore, according to this assumption, the securitisation process assumes the transfer of a given problem from the sphere of politics to the sphere of security.

Ole Wæver and Barry Buzan claim that the essence of this methodology is the assumption that a challenge becomes a security issue, not only because it is objective in terms of the perception of state actors, but it becomes an existential problem when a securitising actor (very frequently the state) argues that something is an existential threat to some reference object and must be dealt with immediately as soon as its purpose is to survive (B. Buzan, O. Wæver, J. de Wilde, 1998).

According to the theory of securitisation, security is identified with survival and is a formulated speech act in verbal or non-verbal form. The key elements of the structure of this process include securitising actors, reference objects and an audience (Musioł, 2018).

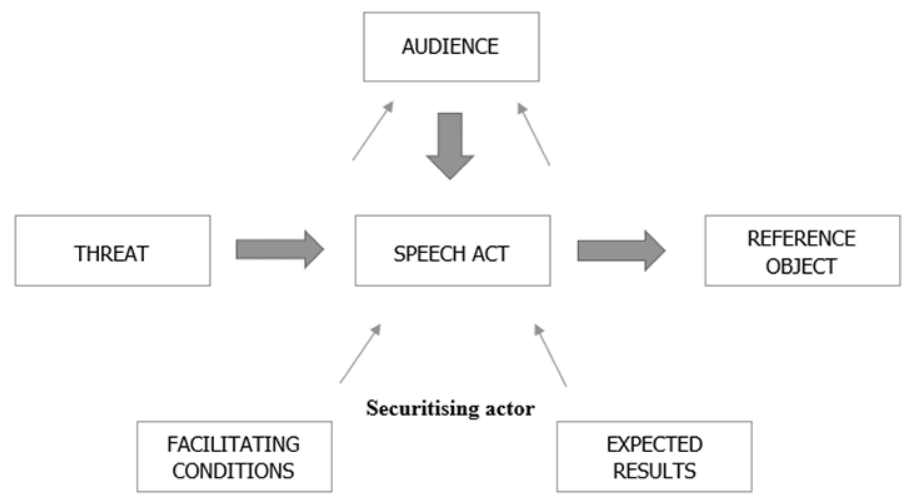

Figure 1. The scheme of the securitisation process

Source: Own elaboration based on Musioł, 2015 and Musioł, 2018. 
The success or failure of the securitisation process results from the proper identification of existential threats, an extraordinary situation, the consequences of breaking the accepted rules and the impact of these actions on the relations between individual units (Musioł, 2018). The conditions facilitating the transformation of the perception of the problem by target groups include, inter alia, the position of the securitising actor and its impact on a potential audience. The threat in this case does not have to be real. It is only important that it is perceived as such.

'The most important aspect of this methodology is the analytical question: how a given issue has been transformed into a security problem or is more or less an element of security policy' (Bueger, 2010).

\begin{tabular}{|l|l|}
\hline Who is a securitising actor? & $\begin{array}{l}\text { State, civic society, international and local non-governemental } \\
\text { organistations, UN agencies, individuals (ecological activists), } \\
\text { politicians and political leaders, governments and political } \\
\text { elites, lobbing groups. }\end{array}$ \\
\hline \hline Who is an audience? & $\begin{array}{l}\text { Public opinion, politicians, political elites, societies, governmen- } \\
\text { tal, non-governmental actors and units. }\end{array}$ \\
\hline What is a reference object? & $\begin{array}{l}\text { Economic and political stability, existential survival, standard } \\
\text { and quality of life, sovereignty, agriculture, economic and social } \\
\text { development, energy, state of health, teritorial integrity etc. }\end{array}$ \\
\hline What is a speech act? & $\begin{array}{l}\text { Statements, declarations, documents, media messages, materials } \\
\text { both in verbal and non-verbal forms etc. }\end{array}$ \\
\hline What is a securitising movement? & An actor just declares a possible threat. \\
\hline What can be a full act of securitisation? & $\begin{array}{l}\text { An audience accepts a given act of speech made by influential } \\
\text { securitizing actors stating that an existential threat exists. Then } \\
\text { it approves for the use of emergency measures. }\end{array}$ \\
\hline
\end{tabular}

Figure 2. Securitisation in practice - sample structure

Source: Own elaboration based on Musioł, 2015 and Musioł, 2018.

To sum up, the idea of securitisation is to transform problems into existential threats and construct suitable conditions to persuade external observers to grant their approval for presented speech acts and extraordinary actions.

Therefore, the present research problem was formulated as follows: the securitisation of Kurdish self-determination is a challenge for the sectarian balance of power in the Middle East. In addition, there is a spiral of opposing national interests of Middle Eastern states that are at odds with the rising aspirations of the Kurds. Thus, the possibility of Kurdish self-determination might be also an existential threat to territorial integrity, the inviolability of borders, constitutional order, national unity etc. for such countries as Iraq, Syria, Iran and Turkey. This complicated situation may lead to the outbreak of armed conflicts. 
In accordance with the theory of securitisation, it is necessary to underline that securitisation is taking place in all possible security sectors, i.e. military (open armed conflict, participation of Kurdish military forces in battle, war victims), political (the open question of Kurdish autonomy, sovereignty), economic (territories close to oil fields, such as Erbil, and the profits gained by the Kurds, as well as their control over them - the case study of Kirkuk in Iraq - economic activities, participation in the global market), societal (the state of the population's health, the standard of living, identity, culture and traditions, including ethnicity and language) and environmental (degradation of areas settled by the Kurds, the natural environment, ecosystems, access to resources and water).

With regard to the specificity of constructed speech acts, politicians and the media have the most valuable influence on the presented facts and their perception in the world. States such as Turkey, Iraq, Iran and Syria have decisive claims in the matter of determining the securitisation process's vector over Kurdish self-determination claims. Nevertheless, it is necessary to underline the role of local and regional media, and associations or nongovernmental organisations in the process of securitisation, such as KURDISTAN 24, Ekurd Daily, ARA News, Peace in Kurdistan, The Kurdish Digital Library, Kurdish Institute of Paris, Washington Kurdish Institute, Kurdish Institute of Brussels, Human Rights Watch and Amnesty International.

More details about the possible avenues open to the securitisation process of Kurdish self-determination and the attitude of selected securitising actors to Kurdish claims in the Middle East can be found in Table 2.

Table 2. The attitude of selected securitising actors to Kurdish claims in the Middle East

\begin{tabular}{|c|c|c|}
\hline $\begin{array}{l}\text { Securitis- } \\
\text { ing actors }\end{array}$ & $\begin{array}{l}\text { Emergency measures, including the pos- } \\
\text { sibility of using military force }\end{array}$ & $\begin{array}{l}\text { Kurdish aspirations as a securitised prob- } \\
\text { lem and their impact on reference objects }\end{array}$ \\
\hline Iraq & $\begin{array}{l}\text { Yes, it is not a rare situation. An example is the } \\
\text { Iraqi intervention in Kirkuk in October } 2017 .\end{array}$ & $\begin{array}{l}\text { Territorial integrity, inviolability of borders, } \\
\text { constitutional order. }\end{array}$ \\
\hline Syria & $\begin{array}{l}\text { Yes, it is not a rare situation. Ambiguous } \\
\text { attitude towards ISIS at the beginning of the } \\
\text { invasion. }\end{array}$ & $\begin{array}{l}\text { Territorial integrity, restriction of rights } \\
\text { to autonomy, regaining control of its own } \\
\text { territory. }\end{array}$ \\
\hline Iran & $\begin{array}{l}\text { Very rare situation. Very radical attitude to the } \\
\text { Kurdish referendum. }\end{array}$ & $\begin{array}{l}\text { Territorial integrity, national unity, limiting } \\
\text { ethnic interference in Iran, support for Shia } \\
\text { influence. }\end{array}$ \\
\hline Turkey & $\begin{array}{l}\text { Very frequent scenario. An example is the } \\
\text { Turkish intervention in Afrin in 2018. Turkish } \\
\text { military forces also launched a very intense } \\
\text { offensive against the Kurds returning from the } \\
\text { battlefield to Turkey. }\end{array}$ & $\begin{array}{l}\text { Limiting the rights of Turkish Kurds, prevent- } \\
\text { ing the strengthening of Kurdish forces in } \\
\text { Turkey, limiting terrorist attacks on security } \\
\text { sector objectives, PKK's challenge. }\end{array}$ \\
\hline $\begin{array}{l}\text { United } \\
\text { States }\end{array}$ & $\begin{array}{l}\text { Possible scenario. Force is used to protect } \\
\text { Kurdish ethnic groups and allies. An example } \\
\text { is the American attack on Russian PMCs in } \\
\text { Syria in February } 2018 \text {. }\end{array}$ & $\begin{array}{l}\text { Zone of influence, hard power, national } \\
\text { interests, the safety of own soldiers, security } \\
\text { of allies, counteracting Syria, Iran, Russia etc. }\end{array}$ \\
\hline
\end{tabular}




\begin{tabular}{lll}
\hline $\begin{array}{l}\text { Securitis- } \\
\text { ing actors }\end{array}$ & $\begin{array}{l}\text { Emergency measures, including the pos- } \\
\text { sibility of using military force }\end{array}$ & $\begin{array}{l}\text { Kurdish aspirations as a securitised prob- } \\
\text { lem and their impact on reference objects }\end{array}$ \\
\hline $\begin{array}{l}\text { Saudi } \\
\text { Arabia }\end{array}$ & $\begin{array}{l}\text { A quite impossible situation due to the strong } \\
\text { relationship between Saudi Arabia and the } \\
\text { United States. Saudi Arabia urged the Kurds } \\
\text { to call off the referendum in 2017 to avoid } \\
\text { tensions in the region. }\end{array}$ & $\begin{array}{l}\text { Regional ambitions, rivalry with Iran, national } \\
\text { interests, control of the fuel market, avoiding } \\
\text { destabilisation in the Middle East, strength- } \\
\text { ening Sunni influence, and in particular, } \\
\text { Wahhabism. }\end{array}$ \\
\hline $\begin{array}{l}\text { Israel } \\
\text { Not willing to use force to protect Kurdish }\end{array}$ & $\begin{array}{l}\text { Own survival and security, weakening op- } \\
\text { ponents in the Middle East, gaining access to }\end{array}$ \\
& $\begin{array}{l}\text { lising the region. } \\
\text { new markets and commercial contracts. }\end{array}$ \\
Union & $\begin{array}{l}\text { Not capable of using force to protect Kurdish } \\
\text { rights to self-determination, which is deter- } \\
\text { mined by European and international law (the }\end{array}$ & $\begin{array}{l}\text { Protection of human rights, support for Kurd- } \\
\text { ish diaspora in Europe, right to autonomy and } \\
\text { protection of ethnic minorities in the Middle }\end{array}$ \\
& $\begin{array}{l}\text { authorisation of the UN Security Council). } \\
\text { East, soft power, rule of law, democratic } \\
\text { standards, political and civil freedoms. }\end{array}$ \\
\hline
\end{tabular}

Source: Own elaboration.

The actions of securitising actors may also lead to a new geopolitical balance of power in the MENA region. Moreover, in this specific securitisation process of Kurdish self-determination, the aspirations themselves can be also seen as a reference object to Kurdish survival because they lead very frequently to radically negative counteractions by Middle Eastern states. Therefore, an important goal of the Kurds is to direct the process of securitisation of their self-determination in the Middle East towards recognising their rights globally, and obtaining the political support of actors in the international arena with a view to the gradual implementation of legal and international subjectivity.

\section{Conclusions}

The present situation of the Kurdish population is currently determined by clear discrepancies in the views regarding the future of Kurdistan, among politicians of states with a high share of the Kurdish population. This is correlated with the tense situation in Iraqi Kurdistan. The Turkish authorities are taking a number of initiatives, but the vast majority are due to pressures from the EU. The situation of the Kurds in Iran or Syria is not much better, where the effects of a long-term assimilation policy (especially in Syria) are visible. In addition, internal divisions and the lack of a coherent position among the Kurdish diaspora (inhabiting many Middle Eastern countries) directly influence the perceptions of the Kurdish community of its own situation and its chances of acquiring a sovereign state. The above dilemmas have primarily geopolitical roots, and form a major obstacle to the formation of a unified state organisation. The situation is worsened by the conviction and, above all, the fear of countries like Turkey, Iraq, Iran and Syria, that a single Kurdish action in the Middle East can trigger a chain of closely linked national liberation claims in the rest of the countries settled by Kurds. Therefore, Kurdish attempts, aimed at articulating the right to 
self-determination, in one Middle Eastern state, imply repression in others. This is largely determined by the fear of increasing Kurdish separatism. For example, the radical actions of states in the Middle East after the Persian Gulf War fit into this context.

The situation of the Mountain Turks (as Kurds are known in Turkish propaganda) is getting worse after the increase of Turkish involvement during ISIS's expansion in Iraq and Syria. Besides, the Turkish government's views on the Kurds remain ambiguous. Turkey was not indifferent to the fate of Kurdish refugees exiled brutally with the use of chemical weapons from Iraq, but in the first half of the 1990s it initiated the exodus of Turkish Kurds to Iraq.

After the failure of the implementation of the results of the Kurdish referendum in Iraq, the Kurdish community's efforts must once again focus on influencing international public opinion, rebuilding trust among allies, ensuring rights and improving the situation of Kurds in individual countries in the Middle East. In this case, the US, the EU and the Kurdish membership of the Unrepresented Nations and Peoples Organization (UNPO) continue to provide important support for the Kurds.

Despite the fact that the right of the self-determination of nations is guaranteed by the Charter of the United Nations, the securitisation process of the Kurdish nation (being at the same time securitising actors, reference objects and an audience) striving for its own sovereign state is extremely complicated. This is due to the conviction that the settlement of the Kurdish issue in one Middle Eastern country will force a chain of claims in other states in the region (Kukułka, 2003, p. 612). Therefore, the consideration of the Kurdish issue in only one state ignoring geopolitical conditions and the situation of the Kurdish population in the rest of the states in the Middle East (especially in Turkey, Syria, Iraq and Iran), in fact, does not reflect the essence of the problem at all. This so-called security dilemma driven by Kurdish claims is identified strongly with a strategic difficulty in relations between states and other actors in the Middle East.

The issue of the largest community in the Middle East, devoid of its own state and legal organisation, has been also complicated by the lack of a cohesive factor in the form of a national and cultural identity. This was undoubtedly the result of the assimilation policies of the states in which the Kurds live.

In addition, the awareness of national separateness and identity among the Kurds has been building for centuries, especially in the so-called Turkish or Iraqi Kurdistan. Furthermore, the lack of intelligence, largely responsible for promoting patriotism, fighting spirit, and the importance of strengthening socio-cultural ties, have not facilitated this task in the securitisation process and are largely used by Middle Eastern states to portray the Kurds as an existential threat to the peace and order in the region (Kołodziejczyk, 2000, p. 252). The situation of the Kurdish community is also complicated by the fact that Turkey is a significant ally and US partner in the Middle East.

The Kurdish issue has frequently been entangled in the strategies of given powers (such as the United Kingdom, the United States or the European Union), with specific objectives 
to be realised in the Middle East (Kukułka, 2003, p. 611). These powers somehow also take part in this game as securitising actors. The ambition of power has overwhelmed the idea of an independent or autonomous Kurdistan. Promises were made by international actors to regulate this urgent issue for the Kurds, but it soon became apparent that the hopes of the community were unnecessarily awakened. This relates especially to actions of the US after the Gulf War. The US encouraged the Kurds to revolt against the Iraqi dictator. J. Kukułka claimed that ' when this highland nation was massacred by Iraqi troops, the US administration was silent with the governments that dealt with the Kurdish minority on their own. The success of Iraqi Kurds was threatened by the rise of their brothers in other countries' (Kukułka, 2003, p. 611). Importantly, US deployment in several Middle Eastern countries, often with distinct or conflicting interests, is a serious barrier to meeting the aspirations of a multi-million strong Kurdish community. Essentially, the factor destabilising the prospects of a Kurdish state is primarily poverty and very often the lack of prospects for the future.

Obviously, there are clashes and party quarrels that undoubtedly diminish the credibility of Kurdish representation. The best example of this is the Kurdish grouping in Iraq, which deteriorated to civil war. This is not conducive to the realisation of the Kurdish goal, which is independence and, in the worst case, autonomy in individual countries of the Middle East (for example, Iraq).

Finally, it is important to point out that, in a sense, there is the advantage of the opposite securitisation rhetoric and the negatively oriented security discourse on the Kurdish national liberation claims in the Middle East. Such a context is in line with both the post-referendum climate in Iraq, the Turkish offensive in Syria, and the withdrawal of US troops from Syria. According to S.A. Cook, 'the U.S. withdrawal from Syria will effectively end the relationship with the Syrian Democratic Forces, the primary component of which is a Kurdish fighting force called the People's Protection Units (YPG) [...] Turkey's overriding concern has always been and will continue to be the destruction of a Syrian Kurdish autonomous zone that the YPG and its political affiliate, the Democratic Union Party, dominate'(Cook, 2018). S. Holland from Reuters UK, however, informed in January 2019 that 'White House national security adviser John Bolton added a new condition on to the U.S. withdrawal from Syria, saying Turkey must agree to protect the United States' Kurdish allies' (Reuters UK, 2019). This is proof that the Kurdish question will again be at stake.

\section{References}

A New Map of the Middle East, Geopolitical Futures 2017, http://ggc-mauldin-images.s3.amazonaws.com/ newsletters/images/Map_3_Enlarge_20170116_TWIG.jpg?v=1484596136294, [access: 10.03.2018]. Banco E., Fight For Kobane May Have Created A New Alliance In Syria: Kurds And The Assad Regime, International Business Times, 10.08.2014, https://www.ibtimes.com/fight-kobane-may-have-creatednew-alliance-syria-kurds-assad-regime-1701363, [access : 07.01.2019].

Bierzanek R., Symonides J., Prawo międzynarodowe publiczne, Warsaw: 2004. 
Bueger Ch., Security as Performation: Securitization, Piracy and the United Nations Security Council, bi-annual conference of the Standing Group for International Relations of the ECPR, Stockholm, European University Institute and Institute for Development and Peace, wrzesień 2010.

Buzan B., Waever O., Regions and Powers. The Structure of International Security, Cambridge Studies in International Relations, Cambridge University Press, Cambridge: 2003.

Buzan B., Wæver O., de Wilde J., Security: a new framework for analysis, CO: Lynne Rienner Publishers, Boulder: 1998.

Charter of the Social Contract, Self-Rule in Rojava, 29 January 2014, https://peaceinkurdistancampaign. com/charter-of-the-social-contract/, [access: 07.01.2019].

Cook S.A., Turkey Is Lying About Fighting ISIS, Foreign Policy, 2018, https://foreignpolicy.com/2018/12/28/ turkey-is-lying-about-fighting-isis/.

Dziś ruszaja w Turcji programy i audycje w języku kurdyjskim, „Gazeta Wyborcza”, 23.03.2006.

El-Ghobashy T., Kurdish leader says he will step down in wake of failed bid for independence from Iraq, „the Washington Post”, October 2017.

Encyklopedia historyczna świata, T. XI., Agencja Publicystyczno-Wydawnicza Opres, Cracov: 2002, s. 391.

European Parliament resolution on Turkey's progress towards accession (2006/2118(INI)), http://eur-lex. europa.eu/legal-content/EN/TXT/?uri=uriserv:OJ.CE.2006.306.01.0196.01.ENG\&toc=OJ:C:2006:30 6E:TOC\#CE2006306EN.01028401, [access: 10.03.2018].

Farouk-Sluglett M., Sluglett P., Iraq Since 1958. From Revolution to Dictatorship, I.B. Tauris. London \& New York: 2003.

Fuad J., Kurdowie i Kurdystan, Wydawnictwo L\&L, Danzig: 2001.

Giedz M., Węzeł kurdyjski, Wydawnictwo Akademickie DIALOG, Warsaw: 2002.

Grgies A., Sprawa Kurdyjska w XX wieku, Wydawnictwo Akademickie DIALOG, Warszawa: 1997.

Holland S., U.S.'s Bolton says Turkey must not attack Kurdish fighters once U.S. leaves Syria, January 6, 2019, Reuters UK, https://uk.reuters.com/article/uk-mideast-crisis-usa-syria/u-s-s-bolton-saysturkey-must-not-attack-kurdish-fighters-once-u-s-leaves-syria-idUKKCN1P009E?utm_cam paign $=$ trueAnthem $\% 3 \mathrm{~A}+$ Trending + Content\&utm_content $=5 \mathrm{c} 32192 \mathrm{e} 04 \mathrm{~d} 3016 \mathrm{~d} 0 \mathrm{ca} 449 \mathrm{a} 7 \& \mathrm{u}$ tm_medium=trueAnthem\&utm_source=facebook\&fbclid=IwAR1NdCyC_33ugqWwt3QgPYq03L 33dv4Lt2rdzXGIX_8_t0Z0q6KtbOqArT0, [access: 06.01.2019].

IRIN, Iraqi Kurdistan has voted for independence. What now?, 27 September 2017, http://www.refworld. org/docid/59ccb6f04.html, [access: 10.03.2018].

Kołodziejczyk D., Turcja, Wydawnictwo Trio, Warsaw: 2000.

Kukułka J., Historia Współczesna Stosunków Międzynarodowych 1945-2000, Wydawnictwo Naukowe Scholar, Warsaw: 2003.

Kurdyjskie wyzwanie, „Gazeta Wyborcza”, 29.04.2005.

Leduc S., The Kurds: The world's largest stateless nation, FRANCE 24, http://www.france24.com/en/20150730who-are-kurds-turkey-syria-iraq-pkk-divided, [access: 10.03.2018].

Musioł M., Regionalny Kompleks Bezpieczeństwa w Azji Środkowej po 1991 r., Dom Wydawniczy Elipsa, monografia, Warsaw: 2015.

Musioł M., Znaczenie sekurytyzacji i sektorów bezpieczeństwa w ramach krytycznych studiów nad bezpieczeństwem, Historia i Polityka, Nr 23(30)/2018, Wydawnictwo Naukowe Uniwersytetu Mikołaja Kopernika, Toruń 2018.

Rascouet A., Al Absary K., How Iraq's Kurdish Independence Referendum Could Impact Oil Markets, Bloomberg, 24.09.2017, https://www.bloomberg.com/news/articles/2017-09-20/iraq-s-kurds-seekindependence-what-impact-for-oil-markets, [access: 14.04.2018]. 
Shaw M.N., International Law, Sixth edition, Cambridge University Press, Cambridge: 2008. Strachota K., Klęska irackich Kurdów i fiasko regionalnych ambicji Turcji, OSW, Warsaw: 2017.

Wituch T., Przemiany tureckie. Dzieje Turcji 1878-1923, Państwowe Wydawnictwo Naukowe, Warsaw: 1980. Zdanowski J., Historia Bliskiego Wschodu w XX wieku, Zakład Narodowy im. Ossolińskich, Wrocław: 2010.

\section{Author}

\section{Marek Musioł}

University of Wrocław, Institute of International Studies, Departmen t of Security Studies, ul. Koszarowa 3 bud. 21,51-149 Wrocław, marek.musiol@uwr.edu.pl 